\title{
Experimental Determination of the Isothermal Compressibility of Drilling Fluids in High Pressures and Temperature
}

\section{Giuliano A. J. C. D. C. Mazoni, Nara A. Policarpo, Nilo R. Kim, Paulo R. Ribeiro}

\begin{abstract}
The present work aims at the experimental determination of the isothermal compressibility of drilling fluids under high pressure and high temperature. For that, a high-resolution PVT (Pressure-Temperature-Volume) cell was used to measure data through the Constant Composition Expansion method. The isothermal compressibility values of the studied fluid were similar to the data found in the literature.
\end{abstract}

Key words: Isothermal Compressibility, Water, Drilling Fluids.

\section{Introduction}

With the recent discovery of huge petroleum reservoirs located at the Pre-Salt area containing light oil of excellent quality, the offshore drilling wells in deep and ultra-deep environments has significantly increased. Currently, these reservoirs are responsible for more than $50 \%$ of the total Petrobras production. The drilling in such environments usually faces severe pressure and temperature conditions which directly influence on the drilling fluid properties. The knowledge of the drilling fluid properties is important in the kick's context. The kick consists of the unwanted gas influx from the reservoir into the well during the drilling. This gas influx may become an uncontrolled fluid eruption (blowout), causing damage to equipment, environment, financial and even human lives $^{1}$. From the thermodynamic perspective, the isothermal compressibility of the drilling fluids is related to its density variation, which is concerned to the effective understanding of the kick control. The isothermal compressibility (c) of a fluid consists of the fractional variation of its volume $(\mathrm{V})$ as a result of the variation of pressure $(P)$ under constant temperature $(T)^{2}$. Therefore, the present work aims to determine the experimental isothermal compressibility of water-based drilling fluid at temperatures of 30,50 , and $80^{\circ} \mathrm{C}$ and pressures up to 8000 psig. The isothermal compressibility of the waterbased drilling fluid was obtained through the measuring of pressure, volume and temperature in a PVT (Pressure-Volume-Temperature) cell, as seen in Equation 1.

$\mathrm{c}=-1 / \mathrm{V}(\partial \mathrm{V} / \partial \mathrm{P}) \mathrm{T}$

\section{Results and Discussion}

Experiments were run by a PVT cell using the Constant Composition Expansion (CCE) method, which consists of the controlled fluid expansion at a constant temperature. Tests were made with the distilled water in triplicate at each temperature $\left(30,50\right.$ and $\left.80^{\circ} \mathrm{C}\right)$ and pressures from 0 to 8000 psig. For each 1000 psig variation in pressure, the volume was registered. The isothermal compressibility of water at $80^{\circ} \mathrm{C}$ is shown on Image 1 . The figure also shows a comparison with results from the literature, $\mathrm{NIST}^{3}$ and Marques ${ }^{4}$, at the same pressure and temperature conditions. As expected, the compressibility changing was small, because water is considered an incompressible fluid. The same behavior was observed for the other studied temperatures.

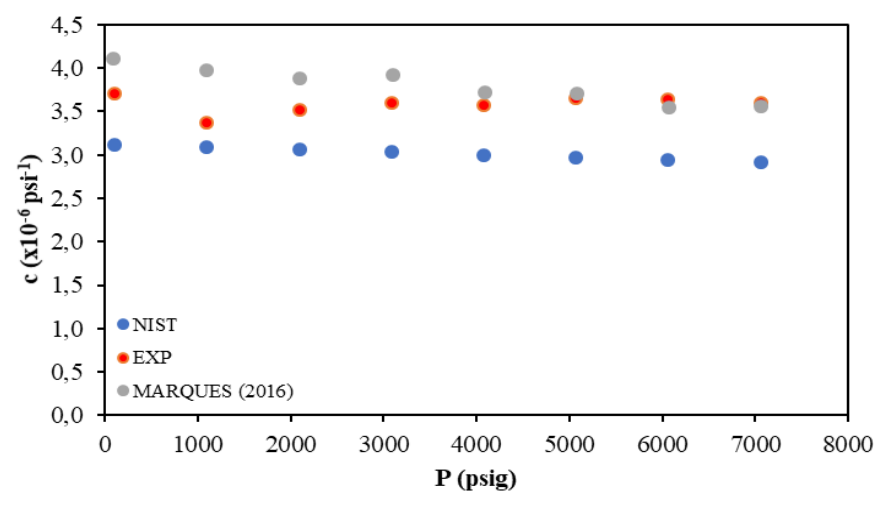

Image 1. Isothermal compressibility of the water at $80^{\circ} \mathrm{C}$.

\section{Conclusions}

The isothermal compressibility of water was satisfactorily obtained through the PVT cell. As expected, the compressibility data for the studied fluid was, on average, 3.5.10-6 $\mathrm{psi}^{-1}$.

\section{Acknowledgement}

The authors are thankful for Petrobras financial support.

\footnotetext{
1 Thomas, J. E. (Org.). Fundamentos de Engenharia de Petróleo. Rio de Janeiro: Interciência, Petrobras, 2001. 271p.

${ }^{2}$ Rosa, J. A.; Carvalho, R. S. and Xavier, J. A. D. Engenharia de Reservatórios de Petróleo. Rio de Janeiro: Interciência, Petrobras, 2011. 808p.

${ }^{3}$ NIST. Isothermal Properties for Water. 2018.

${ }^{4}$ Marques, D. C. Estudo das propriedades termodinâmicas de misturas de metano em olefina linear. Dissertação. FEM, Unicamp, 2016.
} 